\title{
放射線胎児被曝と大䑈発達障害 調査研究の現状と問題点—十
}

\author{
癿山義郎 \\ 名古屋大学環境医学研究所 \\ 464 名古屋市千種区不老町
}

Key Words: radiation, in utero exposure, fetus, brain development, developmental disorder. atomic bomb, mental retardation, microcephaly, intelligence quotient

\section{1. はじめに}

発生, 発育過程の胎児大脳が他の胎児器管・組織に比 べ放射線感受性が高いことは, 被曝による代表的奇形 がヒト，動物のいずれる小頭症である事実が示すとお りである。ヒトの胎児被曝で古くから注目されて来た のは, 広島, 長崎の原爆子宮内被曝による小頭症と精

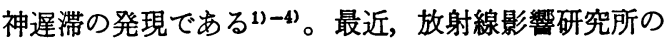
Otake and Schull (1983，1984）は原爆子宮内被曝の データの再評価を行い, 放射線影響では小頭症より精 神遅滞の方が重要で, 大脳皮質の発生が活発な胎生 8 - 15週の被曝によって重度精神遅漁が高率に発現し, その発現率は統計学的にしきい值のない線量・反応関

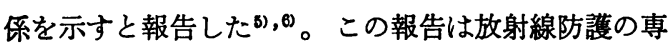
門家の間に大きな反響をもたらし，国際放射線防護委 員会（以下 ICRP と略す）と国連科学委員会（以下 UNSCEAR と略す) は胎児被曝を重点検討課題とし, 1986年にそれぞれレポートを公表した ${ }^{71,8) 。 ~}$

上記の二つの国際機関のレポートは，同じ問題意識 で同じ時期に同じ文献資料を用いて論述しているた め, 脳発達障害に関する内容はほぼ共通している。UNSCEARーReport (1986)の一章 “Biological Effects of Prenatal Irradiation”では, 1977年以降の文献を収集し, げっ歯類の実験動物の知見は質的にはヒトに外挿でき るとの立場で，動物データを広くレビューしている。 ICRP Publication 49 (1986) “Developmental Effects of

† Prenatal Irradiation and Developmental Disorders of the Brain-Present state of investigation and the problem-. Yoshiro KAMEYAMA: The Research Institute of Environmental Medicine, Nagoya University, Furo-cho, Chikusa-ku, Nagoya 464, Japan.
Irradiation on the Brain of the Embyro and Fetus" は「ヒトの中权神経系への放射線影響，とくに精神遅 滯の誘発について，危険な被曝胎战命と低線量での量的 リスクを推定するための資料を得る」ことを目的とし たTask Group of Committee 1 のレポートで, リスク 評価にはげっ歯類の実験データのヒトへの外挿は困難 との立場から, サル以外の実験データの引用は最小限 に止めている。

筆者は実験奇形学の立場から, ICRP-Task Group の一員としてレポートの原稿作成に参画した関係で, 本編では ICRP Publ. 49 の記述とこれに関連するわ れわれの実験成績を紹介し，調査研究の問題点を指摘 したい。

\section{2. 脳の発生とその異常}

\section{$2 \cdot 1$ 脳発生異常の奇形学的特徵}

脳を構成する主要成分のニューロンは，それらの局 在する部位によってそれぞれ異なった機能を持ち，し かもそれらが相互に連動して多様な中权機能を現わす 点で, 単一の器官として最も複雑な構造体とみなすこ とができる。このため, 細胞の増生, 生理的細胞死, 遊走, 配列, 細胞間連絡等の発生事象が時間的にも空 間的にも䇴密に進行することが要求される。外因によ って脳発生異常が起こり易い理由として, 上述の発生 の複雑さに加えて，つぎの三つの特徵をあげることが できる(表 1 )。

(a) 発生異常の感受期が長い: 他の器官に比べ中权 神経系は最す早く発生を開始しながら成熟に至る期間 が長い。とくに脳では組織発生の期間が長いため，感 受期はヒトではほぼ全胎生期間にわたる。

（b）未分化神経細胞は外因に対し障害感受性が高 い: 増生中の未分化細胞は, 放射線, 重金属, 微生物 
表 1 大脳の発生学的特徵と外因性発生異常

\begin{tabular}{|c|c|c|}
\hline & 発生宇 & 外因性発生異常 \\
\hline & $\begin{array}{l}\text { 発生, 発育の期間が長い。 } \\
\text { 最も早く発生が開始しな } \\
\text { がら成熟に至る期間が最 } \\
\text { も長い。 }\end{array}$ & $\begin{array}{l}\text { 感受期がきわだって } \\
\text { 長い。 }\end{array}$ \\
\hline 2) & $\begin{array}{l}\text { 胎生期の特定の発生段階に } \\
\text { おける未分化神経系細胞の } \\
\text { 増生能が高い。 }\end{array}$ & 障害感受性が高い。 \\
\hline & $\begin{array}{l}\text { 神経細胞は胎生期に産生完 } \\
\text { 了し, 以後再生しない。 } \\
\text { ニューロン構成が部位的, } \\
\text { 機能的に多様である。 }\end{array}$ & $\begin{array}{l}\text { 障害を受ける発生段 } \\
\text { 階に応じ, 多彩な非 } \\
\text { 可逆的機能欠陥をむ } \\
\text { たらす。 }\end{array}$ \\
\hline
\end{tabular}

感染，アルキル化剤，アルコール等多くの環境因子に 感受性が高い。しかも他の器管原基に障害を及ぼさぬ 低量, 低濃度で細胞障害作用を現わす点に注目する必 要がある。

（c）生後に遅発性に多彩な非可逆的機能欠陷をもた らす：脳の各部位を構成するニューロンはそれぞれ異 なった時期に産生され，それらは分化した後は再生し ない。このため胎生期のある特定の時期の侵襲は脳の 限られた構造単位を選択的に障害し, 通常の形態学的 検查では発生異常を捉え難い状態でも，しばしば重篤 な機能欠陥を露呈する。

\section{$2 \cdot 2$ 脳の器官発生とその障害}

器官発生は神経外胚葉から成る神経板が神経管を形 成し，頭部神経管が前脳胞，中脳胞，菱脳胞の三つの 脳胞に分かれ，頭端の前脳胞が左右二つの終脳に分割 し，これが大脳の原基となる。

脳の器官発生障害の最初の臨界期は頭部神経管の閉 鎖時期（ヒト胎生 3 週）で，閉鎖障害によって無脳 (症), 脳髄膜へルニアが成立する。第 2 の臨界期は前 脳胞の分割する時期（ヒト胎生 4 週）で，分割の障害 によって単前脳 holoprosencephaly が成立する（表 2)。これらの脳奇形は出生後長期間生存できないも のが多い。

$2 \cdot 2 \cdot 1$ 器官発生障害による脳奇形の奇形学的特徵

（a）奇形成立の感受期が短く，時期特異性が強い： 神経管の閉鎖の開始より頭部と尾部で完全に閉鎖が完 了するまでの時間は，マウス，ラット1日程度，八ム スター 0.5 日，ヒトでは数日以内とみなされる 前脳胞より終脳形成は，マウス，ラット 1 日程度, 七
表 2 大脳の器官発生 organogenesis とその障害

\begin{tabular}{|c|c|c|c|c|}
\hline$\frac{\text { 胎 }}{\text { マウス }}$ & $\frac{\text { 齢 }}{\text { ヒト }}$ & 器官発生 & 発生障害 & $\begin{array}{l}\text { 奇 形 } \\
\text { (organogenetic } \\
\text { malformations) }\end{array}$ \\
\hline - 7日 & 2 週 & 神 経 板 & & 脳 \\
\hline-8 & 3 & 神経管形成 & 閉金 & $\begin{array}{l}\text { 脳 } \\
\text { 頭 } \\
\text { 蓋 } \\
\text { 破 }\end{array}$ \\
\hline 8 & $3-4$ & 前 脳 胞 & & \\
\hline 9 & 4 & 脳 & & Holoprosencephaly \\
\hline
\end{tabular}

トではやはり数日以内と推定される。したがって，催 奇形因子がこの期間を外れて作用した場合は奇形は成 立しない。

(b) 組織の障害感受性は高いが修復能力も強い: 器 官発生の段階の脳は未分化神経系細胞のみで構成され ているため, 催奇形因子によって容易に致死的損傷を 受けるが，損傷を免れた細胞の増生による修復も活発 に起こる。すなわち催奇形因子の侵襲によってすべて の胎芽は組織損傷を受けるが，臨界期を外れて侵襲が 及んだ胎芽では損傷が修復されて異常が残らぬため, 終局的な奇形の発現には all or none の傾向がある。

\section{$2 \cdot 3$ 大脳の組織発生とその障害}

器官発生の障害による奇形を持った胎児は出生前に 死亡する場合が多く, 出生後も長期生存は期待できな いため, 臨床医学の対象となる割合が組織発生異常を 持つ患児に比べ低い。組織発生段階に起こる障害は形 態異常は軽いが機能的欠陷は強く, しかも生存率は比 較的高い。このため, 臨床的に問題になる外因性脳発 達障害の主要部分は組織発生障害によるとみてよい。

大脳外套の組織発生は, 脳室壁での未分化細胞の分 裂，分裂を終わった未熟ニューロンの皮質領域への遊 走, 皮質原基の形成, ニューロン間の線維連絡, シナ プス形成，グリア増生，白質の分化，ミェリン形成の 過程を経て行われる。

終脳形成後なおしばらくは脳実質は未分化増生細胞 のみから構成されているが，ヒト胎生 6-7 週に一部 の細胞は分裂を完了して遊走を開始し, 胎生 7 週には 皮質原基の形成が始まる。脳室壁における皮質ニュー ロンの産生は胎生 8-15週に最も活発で，新皮質二=

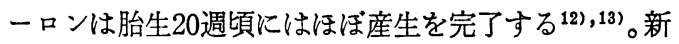
皮質領域への遊走には二つの波があり，第 1 波は胎生 7-10週，第 2 波は第 1 波より大きく胎生11-16週に 起こる ${ }^{14)}$ 。ニューロンの遊走による皮質の構築は，後 から遊走して来た細胞が先着細胞の上層に位置するい わゆる inside-out の順序で敩密な時間的スケジュール 
表 3 大脳外套の組織発生 histogenesis とその障害

\begin{tabular}{|c|c|c|c|c|c|}
\hline \multicolumn{2}{|c|}{ 胎 } & 齢 & \multirow{2}{*}{ 組 織 発 生 } & \multirow{2}{*}{ 発 生 障 害 } & \multirow{2}{*}{$\begin{array}{c}\text { 奇 } \\
\text { (histogenetic } \\
\text { malformations) }\end{array}$} \\
\hline$\checkmark$ & ウ ス & ト & & & \\
\hline \multicolumn{2}{|c|}{ 11日 } & 6 週 & 細胞遊走開始 & 増生細胞の死滅, & 奇形性水頭症, 小頭症, 脳梁欠損, \\
\hline \multicolumn{2}{|c|}{ 13日〜 } & $8 \sim$ & 皮質原基形成 & 分裂阻止, 遊走の阻害, & 灰白質異所形成, 皮質構築異常, 脳 \\
\hline \multicolumn{2}{|c|}{ 17日 } & 20 & 皮質神経細胞の産生完了 & 神経細胞の発育障害 & 回異常（無脳回, 脳回肥厚, 小脳回） \\
\hline \multicolumn{2}{|c|}{ 出生〜 } & $20 \sim$ & 皮質の層構築 & & \\
\hline \multicolumn{2}{|c|}{ 生後 $1-2$ 週 } & $20 \sim 24$ & 皮質神経細胞分化 & & \\
\hline \multicolumn{2}{|r|}{ - } & 7 月 & 主要脳回出現 & & \\
\hline \multicolumn{2}{|r|}{$1-2$ 週 } & 9 月〜 & 髄鞘形成 & & \\
\hline
\end{tabular}

で行われる。形成された大脳新皮質では, ニューロン の発育, 樹状突起の分枝, シナプス形成, グリア増生, 血管網の発育等が進行し，これらの活発な新生児期は vulnerable period ${ }^{15)}$ とよばれ，外的侵襲によって脳発 育障害と破壊性病変が起こり易い。

胎生期の催奇形処理による実験動物の大脳組織発生 障害の主体は, 未分化細胞の致死, 増生の障害による 構成ニューロンの不足および未熟ニューロンの遊走障 害による皮質構築の乱れで，代表的発生異常は奇形性 水頭dysgenetic hydrocephaly, 小頭, 脳梁欠損, 灰白質 異所形成, 皮質層構筑異常, 脳回異常である（表 3 ）。 大脳の組織発生障害に関連する最近の神経生物学的 研究として注目されるのは, ニューロンの生理的細胞 死と細胞接着因子 (CAM) である。一般に発生過程の 器官では細胞の過剰産生と選択的致死が起こることが 実験的に知られている。中权神経系においても，標的 細胞への過㮃な数の線維連絡や誤った連絡が起こった 場合にそのニューロンを選択的 に死隇除去させて, 適正な細胞 に適正な数で連絡したニューロ ンのみを残す内在性のメカニズ ムが働いている(16)。これは外因 性細胞死の役割を考える場合に 重要で, 正常の脳の発生過程に 起こる大量の生理的細胞死に比 べれば外因によるわずかの細胞 死はそれほど大きな役割を持た ぬとの見方も出てくる。しか し, 外因性の細胞死が生理的細 胞死の内在的プログラムを攪乱 する可能性も無視できない。今 後検討すべき重要課題の一つで あろう。
ニューロンの遊走が受動的な位置移動でなく，能動 的な細胞運動で，細胞表面あるいは細胞間物質が関連 していることが知られている17)。Edelman (1985) ${ }^{18)}$ は ニューロン相互認識に関わる N-CAM, ニューロンと グリアの結合に関わる neural-glial CAM の役割を報 告しており，これら因子についての研究は脳の組織発 生とその異常の機序に新しい展開をもたらすと期待さ れる。

$2 \cdot 3 \cdot 1$ 大脳の組織発生障害の奇形学的特徵

(a) 感受期が長く時期特異性が強くない: 大脳の組 織発生には長い期間を要し，その主要期間を通じて障 害感受性の高い未分化細胞が存在するため，この期間 のいずれの時期に侵襲が及んです，程度と部位に違い はあっても, 増生や遊走が障害されて発生異常がもた らされる（図 1 )。

(b) 障害感受性は器官発生段階に比べ低いが，修復 能力も低い。組織発生の過程には感受性の低い分化し

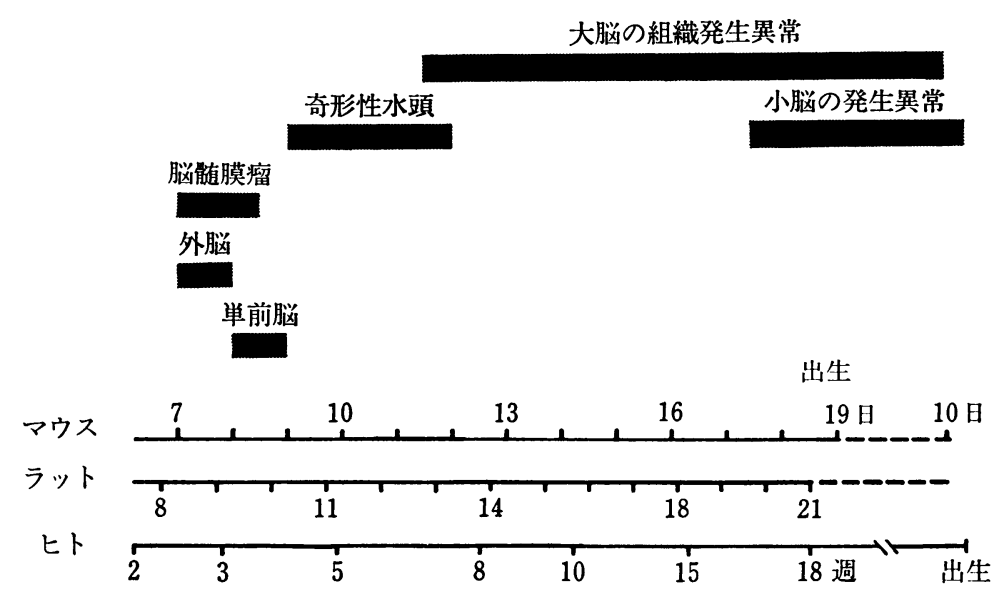

図 1 マウス,ラットにおける外因性脳発生異常の成立感受期と 対応するヒト胎龊 (Kameyama $\left.{ }^{20)}, 1985\right)$ 
た細胞が存在し，その数が増えて行くため，器官レベ ルの障害感受性は当然低下して行く。乙かし，増生細 胞の数もその増生能も低下するため, 組織損傷の修復 力も弱く, 細胞数の不足, 配列の異常などの組織レベ ルの障害が残り易い。

\section{3. 放射線による大脳発達障害}

\section{$3 \cdot 1$ 動物実験のヒトへの外挿の難しさ}

放射線子宮内被曝の七ト症例か 40 年以上前の医療被 曝と原爆被曝に限られている現状では, 実験的研究の 役割が大きいが，ヒトのリスク推定の資料とするには 難問が山積している。第 1 の基本的難問は放射線によ る脳発生異常のメカニズムで，ニニーロンの遊走障害 や遅発性のニューロンの発育障害などの非致死性変化 が，放射線の直接作用によるものか，細胞死の続発性 变化かは未解決である。また脳の正常発生と正常機能 の発現に不可欠な生理的細胞死が放射線によって影響 を受けるか否かるまったく不明である。ヒトと動物の 胎児の障害感受性の比較推定を困難にする難関の一つ は, 脳発生の各事象の時間的経過の違いである。マウ ス，ラットで1日間で起こる発生事象がヒトでは数日 以上要することが多いが，この時間のスケールをその まま細胞増生速度などに単純にあてはめることはでき ない。個々の発生事象の進行度の細胞レベルでの比較 が必要であるが，未だ手はつけられていない。

ヒトで問題となっている放射線誘発精神遅滞につい ては，ヒトと実験動物の間の大脳の系統発生的隔たり が大きく, しかも動物では大脳の構造と機能拉よび行 動との関連についての知見が不十分な現状では, 実験 動物をモデルとすることは無理であることはいうまで るない。しかし，ヒト精神機能の主座をなす大脳皮質 の発生は，その形態学的特徵と発生過程は基本的に哺 乳動物に共通である。このため，ヒトと実験動物の子 宮内被曝児に共通する形態学的発生異常については, 実験知見はヒト大脳発達障害の理解に有用と考える。

\section{$3 \cdot 2$ 実験的研究}

UNSCEAR-1986 Report が1977年以降の文献を広 範に収集し紹介しているので詳細は省略し，本項では ヒト小頭症と精神通漁に関連する実験成績の概略を紹 介する。

ヒト重度精神遅滞児の剖検例と実験動物の外因性脳 組織発生異常に共通してみられる代表的な大脳皮質の 形態学的变化は，(1)皮質細胞数の不足 (強度であれば 外形で小頭)，(2層構筑の不整，灰白質異所形成，(3)
ニューロンの発育不全, 樹状突起の分枝不足, (4)樹状 突起束の形, 分布の異常, である。原爆例を含む七ト 放射線子宮内被曝児の剖検例でも，これらのいくつか が報告されている(後述)。サルの実験では, 胎生75 日（ヒト胎生19週に相当）に $r$ 線 $2.0 \mathrm{~Gy}$ を被曝した リスザルに，皮質の厚さの減少，皮質細胞数の不足， 樹状突起の分枝不足, 樹状突起棘の数の減少が報告 されている19)。

このため，上述の大脳皮質の形態学的変化を量的指 標としてどの発生段階が最も感受性が高いかを明らか にし，その発生段階での線量効果を調べることがヒト のリスク評価の質的資料として価値があると考穴る。

\section{$3 \cdot 2 \cdot 1$ 大脳皮質発生障害の最高感受期}

（a）皮質細胞数の不足：小頭に代表される大脳外套 の発生異常は感受期が長い特徵があるが (図 1), こ の期間の中でとくに皮質細胞数の不足（皮質厚さ $\times$ 皮 質細胞密度の計測による）を起こし易い胎龄を0.5$1.0 \mathrm{~Gy}$ の X 線を被曝したマウスについて調べたとこ

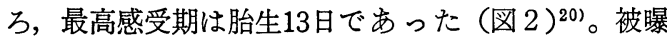
直後の脳室壁の未分化細胞の細胞死の頻度と分裂遅延 時間を $0.25 \mathrm{~Gy}$ を被曝したマウス胎仔で調べたところ， やはり最高感受期は胎生13日であった ${ }^{21) 。 す な わ ち ， ~}$ この胎㱓の被曝による未分化細胞の細胞死の増加が, 生涯残る皮質細胞数の不足をるたらす主因であるとみ なすことができた。ラットでは最高感受期は胎生 15 日22)，モルモットでは胎生21日 ${ }^{23)}$ であった。これらの 成績から，放射線小頭症には明瞭な最高感受期が存在

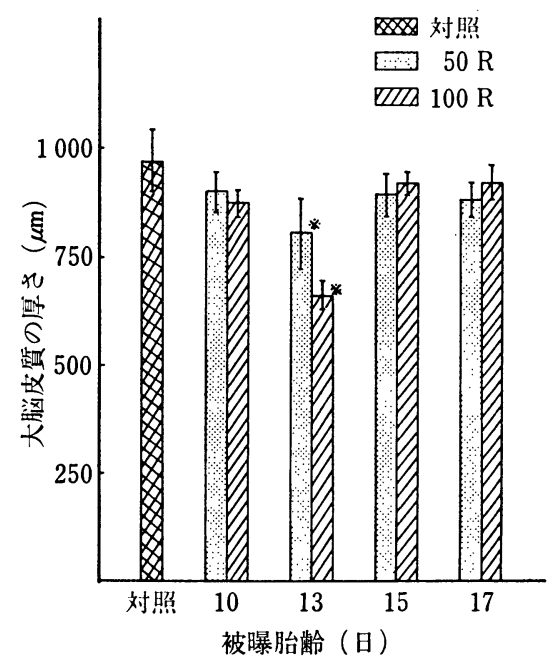

図 2 胎生10-17日に $\mathrm{X}$ 線50 R，100 Rを被 曝したマウスの生後 12 週の頭頂部大脳 新皮質の厚さ $\left(\right.$ Kameyama $\left.{ }^{20)}, 1985\right)$ 
し, その時期は, 胎仔大脳の脳室壁の未分化細胞から ニューロンの産生が活発に起こり, 大脳新皮質原基の 形成が始まる発生段階に一致し，この発生段階の未分 化神経系細胞が放射線致死感受性が最も高いことが明 らかになった。

(b) 皮質層構築の乱れ：1.0 Gy 以上の高線 量被曝 がニューロンの遊走障害による灰白質異所形成を起こ すことは知られているが, radioautoradiography によ る組織学的観察により微細な皮質構筑の乱れは 0.25 Gy の低線量でも起こり，その高感受期はマウス胎生 13ー15日であった24)。

(c) 皮質ニューロンの樹状突起の不足 : 胎生 $13-17$ 日に0.1-1.0 Gy のX線を単回被曝したマウスの新皮 質第 5 層の錐体細胞の樹状突起の分枝数を計測したと ころ, 分枝数の不足は胎生13-15日被曝仔に明瞭で, 皮質細胞数の不足（未分化細胞の致死）に比べて感受 性が高く，感受期が長く続く点が注目される(因 3$)^{23) 。 ~}$

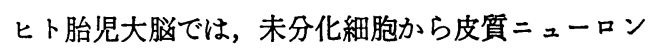
への分化と皮質領域への遊走は胎生 8 週に始まり, = ニーロンの産生は胎生15週頃まで活発であることが知 られている ${ }^{15)}$ 。ヒト原爆小頭症の最高感受期は胎生 89 週で (後述), この時期の大脳の発生段階はマウス 胎生13日に相当する。小頭の最高感受期が皮質 ニュー ロンの産生が始まって間もない時期に一致する点は, 実験動物の知見とヒト症例はよく一致している。

原爆子宮内被曝による重度精神遅滞の高感受期は胎 生 8-15週で (後述), 小頭の高感受期と同し時期に始 まって長く続いている。マウス皮質ニューロンの樹状

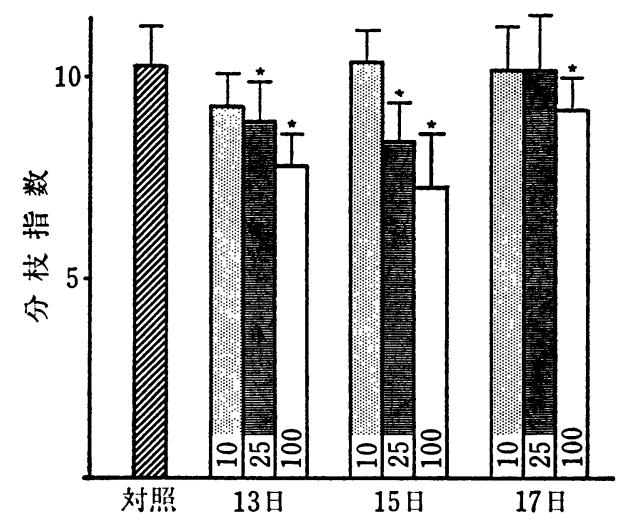

困 3 胎生13-17日にX線10,25, $100 \mathrm{rad}(0.1$, $0.25,1.0 \mathrm{~Gy})$ を被曝したマウスの生後12 週の大脳新皮質第 5 層ニューロン樹状突起 の分枝指数（終末分枝数/胞体より出る枝 数) (Kameyama 5 $\left.{ }^{25)}, 1986\right)$
突起の発育障害の知見は, 高感受期と大脳機能に関連 する形態学的変化の点において, ヒト知見に対応して いるとみなすことができる。

\section{$3 \cdot 2 \cdot 2$ 大脳皮質発生障害の線量効果}

(a) 被曝直後の細胞死々細胞周期の変化：マウスの 最高感受期の胎生 13 日に $0.03-0.25 \mathrm{~Gy}$ のX線を被曝 した胎仔大脳の未分化細胞の細胞死の頻度は $0.03 \mathrm{~Gy}$ と0.25 Gy の間では直線性を示し26),27)，同じ線量を 被曝したラット新生仔の小脳外顆粒層の未分化細胞の 細胞死の線量一反応関係にきわわてよく似ている28)。 また, マウス胎生13日に0.1-1.5 Gy を被曝した胎仔 大脳の未分化細胞の細胞周期の変動は, $\mathrm{G}_{2}$ 期の延長 に明瞭な線量効果関係が見られている21)。 未分化神経系細胞の細胞死が被曝 5- 6 時間をピー クとして起こり, $0.03 \mathrm{~Gy}$ の低線量で増加する点は, 胎児大脳の際立った高感受性を示するので, 分割照射 の実験によりこれらの細胞には放射線障害の回復がみ られないことが示唆されている26)。さらにこれら未 分化紐胞の致死感受性は $\mathrm{S}$ 期, $\mathrm{G}_{2}$ 期のみでなく, $\mathrm{G}_{1}$ 期あるいは $G_{0}$ 期も高いことを示唆する成績も得られ ている25)。

(b) 出生後の成仔にみられる大脳発生障害 : 高感受 期の胎生13-15日に被曝したマウスの新皮質第 5 層二 ニーロンの樹状突起の分枝数の不足をもたらす最低線 量は0.1 Gy と0.25 Gy の間にあり（図 3), 皮質細胞 の不足を検出できる最低線量は $0.25 \mathrm{~Gy}$ と $0.5 \mathrm{~Gy}$ の 間にある。ほぼ同様のマウスの実験条件で行われた外 国の報告では, 皮質と脳梁の厚さの減少は0.25 Gy 以 上で直線性の線量効果関係を示し, 皮質より脳梁の厚 さの減少が著明と報告されている29, また, 皮質二= 一ロンの先端樹状突起の走行の乱れが，0.125 Gy 以 上でやはり直線性の線量関係を示すデータが得られて (る30)。モルモットでは, 小頭の最高感受期の胎生 21 日の $\gamma$ 線0.1-1.0 Gy の被曝によって, 脳重量の低下 に直線性の線量関係が見られている23)。動物種によっ て放射線誘発大脳発生障害の高感度指標は異なるが, $0.1-0.25 \mathrm{~Gy}$ レベルの低線量によって脳機能に関わ る構造の発育が障害される実験データは興味深い。

胎仔大脳の未分化細胞の高い致死感受性は放射線生 物学の重要なテーマであるが，リスク推定の基礎資料 として有用な実験知見は, 被曝直後の細胞死によって どの脳の部位のどれたけけの皮質ニニーロンが不足すれ ば生後の大脳機能に永続的な障害がもたらされるかで あろう。前章で述べた通り，哺乳動物では胎生期に過 剩なニニーロンを産生し機能発現の段階になって余分 
なニューロンを排除していくとすれば16)，0.1 Gy 以 下の被曝によるわずかの細胞死の増加がただちに機能 欠陥につながるとは考兄難い。今後の重要な課題は細 胞の非致死的変化の性格の検索である。

\section{$3 \cdot 3$ 七治療用放射線被曝例}

\section{$3 \cdot 3 \cdot 1$ 子宮内被曝例}

子宮内で高線量放射線を被曝すると，小頭と精神遅 滞が成立することは 1920 年代から知られ，Murphy （1947）の38例，Dekaban（1968）の26例の集計報告が ある ${ }^{31,322}$ 。被曝胎路命は大半が20週以前であったが， それ以後の被曝によるものも報告されている。線量の 記載のない症例が多いが，高線量被曝児のかなりの数 が正常児であった事実から見て，小頭には比較的狭い 高感受期が存在するか，幅の広い感受性の個体差が存 在することが䚐われる。いずれにしても治療用放射線 被曝は1940年以前の古い症例が大部分で，線量が不明 確のため, リスク評価の資料としての価値が低い。

診断用 X線の胎児被曝の疫学報告 ${ }^{33)-351}$ は，いずれ も線量と被曝胎秢が不正確で，乙かも妊娠 6 月以後の 母の骨盤計測や胎児奇形の疑いで検査した例のため， 放射線との因果関係は不明である。

\section{$3 \cdot 3 \cdot 2$ 幼児期の頭部 X線被曝例}

ヒトは未成熟な大脳の状態で生まれてくるため，乳 幼児の脳への被曝も大脳発達障害をもたらすことが知 られている。治療に用いた $10 \mathrm{~Gy}$ 以上の高線量の頭部 被曝による幼児の脳機能障害の古い記録があるが，最 近の報告では $1 \mathrm{~Gy}$ レベルでも脳機能障害をるたらす といわれる。頭部白秚の治療のため脳表面に1.5-1.75 Gy のX線を被曝した小児は，非被曝児に比べ，IQ 值, 学業成績, 心理テストの成績が低く, 最終学歴も 低いと報告されているが36),37)，線量-効果関係は示さ れていない。なお，X線による頭部白癖の治療は1910 年 - 1959年に欧米では 2 万名以上の小児に適用された が，1960年以降はまったく行われていない。

\section{$3 \cdot 4$ 広島, 長崎の原爆被曝例}

$3 \cdot 4 \cdot 1 \quad$ 小頭および頭围減少

原爆による推定被曝線量および被曝胎秢と小頭の発 現の関係はよく知られているが2-4)，リスク評価の点 で注目されるのは，広島例で小頭の最高感受期が胎生 8-9 週にある点である ${ }^{3)}$ 。この胎龄の大脳の発生段階 は，マウス胎生13日，ラット胎生15日，モルモット胎 生 21 日に相当し, 皮質 ニューロンの産生が活発に始ま る時期に当たる点はヒトとよく一致している。
原爆子宮内被曝児の 4 例の剖検例のうち，精神遅滞 を示さぬ 2 例と胎生 31 週に $0.01 \mathrm{~Gy}$ 以下の被曝の 1 例 には脳に明膫な变化はなかった。しかし，胎生12週に $3.75 \mathrm{~Gy}$ を被曝した 1 例の精神通滞児には，小頭，小 角膜之網膜形成不全を伴う両側小眼球，大脳側脳室周 辺の広範な灰白質異所形成が認められた ${ }^{381,399}$ 。灰白 質異所形成の存在は, 実験動物と同様にヒトでもニュ 一ロンの遊走障害が放射線で起こり得ることを示し， 大脳の機能欠陥に関わる形態発生異常の一つとして重 要なことを示唆する貴重な例である。

子宮内被曝児の頭囲測定のデータの再評価では, 18 歳時の頭囲は線量の増加に伴って直線性の低下を示し たと報告されている。身長も線量に伴って低下する が，身長と頭囲との相関はないといわれる40)。

\section{$3 \cdot 4 \cdot 2$ 重度精神遅滞}

放射線影響研究所の Otake and Schull (1983，1984) は子宮内被曝児1 599例（広島1 251例，長崎348例）の らち, 重度精神遈滞30例について, 被曝線量と被曝胎 齢之の関連を再評価した5，6)。30例中18例は小頭（平 均頭囲一 2 標準偏美）で12例は正常頭囲であった。 17藏までに発見された重度精神達滞の診断は，IQ テ ストでなく，(1)日常の簡単な計算や会話ができない， (2)自身で身のまわりの世話ができない，(3)独りでは何 もできない，(4)施設に入所，の臨床所見に基づいて行 われた。胎内週齢は最終月経の開始日から計算した日 数から14日を引き，これを 7 日で割って算出し, 胎児 被曝線量は $\mathrm{T} 65 \mathrm{DR}^{411}$ を用いた。

再評価の成績は表 4 ，図 4 亿示す通りで，(1)胎生 7 週以前と26週以後の $0.01 \mathrm{~Gy}$ 以上の被曝には重度精神 遅滞の発現はなく, 胎生 8-15 週と 16-25週の被曝群 のみに発現，(20.01 Gy 以上の被㩧のうち 8-15週被 懪群の重度遅滞は17名で，16-25週被曝群 4 名の約 4 倍の発現, (3)胎生 8-15週被曝群の重度遅滞の線量-発 現率関係は統計学的に直線性を示し，しきい値がない 直線関係を仮定した場合のリスクは0.4 Gy ${ }^{-1}$ と報告し ている。

本報告は重度精神遅滞の最高感受期が胎生 8-15 週 であることを明らかにしたが，これは前章の動物実験 の感受期の知見に一致し，大脳皮質 $ュ$-ロンの産生 と遊走が活発な期間の胎児大脳が最も放射線感受性が 高いことをとトで実証した点できわめて貴重なデータ である。この報告で国際的に論議の対象となっている 点は，最高感受期の被曝における線量一反応関係の「直 線性 linearity」である。この linearity はデータを処 理した場合に「linear であると仮定することを統計理 
表 4 広島，長崎の原爆子宮内被曝児の被嚗線量および被嚗胎齢と 重度精神遅滞児の発現数

\begin{tabular}{|c|c|c|c|c|c|}
\hline \multirow{2}{*}{ 胎 齢 } & \multicolumn{5}{|c|}{ 被 曝 線 量 (Gy) } \\
\hline & $<0.01$ & $0.01-0.09$ & $0.10-0.49$ & $0.50-0.99$ & $1.00+$ \\
\hline \multicolumn{3}{|l|}{ 全妊娠期間 } & \multicolumn{3}{|l|}{ 両市を合併 } \\
\hline 被 曝 児 & 1085 & 292 & 169 & 34 & 19 \\
\hline 精神遅滞児 & 9 & 4 & 4 & 6 & 7 \\
\hline$\%$ & 0.8 & 1.4 & 2.4 & 17.6 & 36.8 \\
\hline \multicolumn{6}{|l|}{ 0-7 週 } \\
\hline 被 曝 児 & 210 & 55 & 26 & 2 & 2 \\
\hline 精神遅滞児 & 1 & 0 & 0 & 0 & 0 \\
\hline$\%$ & 0.5 & 0.0 & 0.0 & 0.0 & 0.0 \\
\hline \multicolumn{6}{|l|}{ 8-15 週 } \\
\hline 被 曝 児 & 257 & 69 & 50 & 13 & 9 \\
\hline 精神遅滞児 & 2 & 3 & 4 & 4 & 6 \\
\hline$\%$ & 0.8 & 4.3 & 8.0 & 30.8 & 66.7 \\
\hline \multicolumn{6}{|l|}{ 16-25 週 } \\
\hline 被 曝 肾 & 312 & 86 & 45 & 15 & 5 \\
\hline 精神遅滞児 & 2 & 1 & 0 & 2 & 1 \\
\hline$\%$ & 0.6 & 1.2 & 0.0 & 13.3 & 20.0 \\
\hline \multicolumn{6}{|l|}{ 26週以上 } \\
\hline 被 曝 呪 & 306 & 82 & 48 & 4 & 3 \\
\hline 精神遅滞児 & 4 & 0 & 0 & 0 & 0 \\
\hline$\%$ & 1.3 & 0.0 & 0.0 & 0.0 & 0.0 \\
\hline
\end{tabular}

$1 \mathrm{~Gy}=100 \mathrm{rad}$, ICRP Publ. $49^{7)}$ より引用; 原著は Otake and Schull: RERF TR $1-83^{5)}$

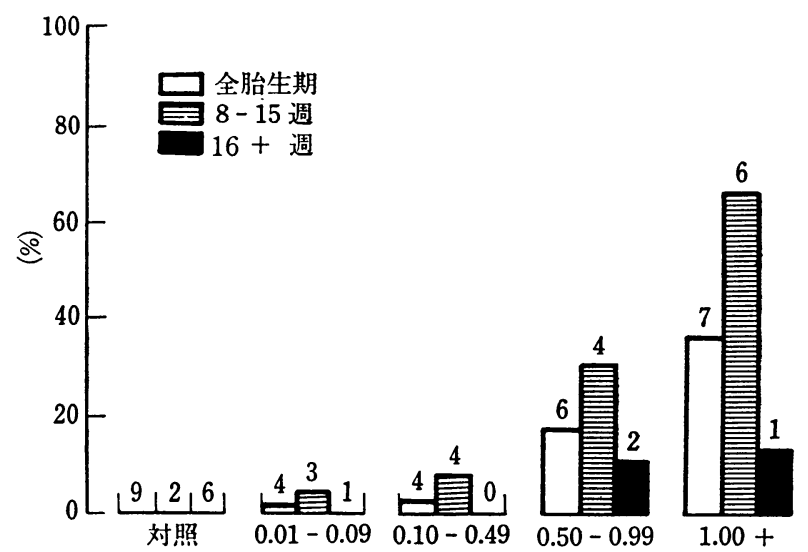

被曝線量 (Gy)
図 4 広島, 長崎の原爆子宮内被曝呪中の重度精神遅滞児の 発現頻度。ヒストグラム上の数字は例数, 各被曝線量 群の平均線量はそれぞれ $0,0.04,0.23,0.72,1.16 \mathrm{~Gy}$ (ICRP Publ. $49^{7)}$ より引用; 原著は Otake and Schull: RERF TR 1-83')

論的に否定できない」と解釈すべきで，この論理を放 射線防護の立場から便宜的に設定した「確率的 stoch- astic」の区分に短絡させるのは無 理であろう。しかし，本報告はヒ 卜子宮内被曝で低線量域での線量 関係が示されている唯一のデータ であり，放射線防護の関係者にと っては無視できないのも事実であ る。

上述のデータに対して問題点と されている主なものは，(1)重度精 神遅滞の診断は適切であったか, (2)精神遅滞は正常との連続形質 で, 外的要因の強さに伴って症度 が変化する。これを二者択一で正 常と重度遅滞に分けて線量-発現 率関係を取り上げるのは不適切, (3)放射線以外の精神漣滞をむたら す要因について検討は十分なされ たか, (4)例数が少ないため, 被曝 線量と被曝胎糩の推定を誤った例 が混在すれば統計結果はどらなる か，(5)放射線の個体発生への影響 は単一の病理過程の㷌結でなく多 細胞現象の代表的なるので, 線 量一反応関係の直線性を支持する 発生生物学的根拠はない。

ICRP Publ. 49(1986) ${ }^{7)}$ と UNSCEAR-1986 Report $^{8)}$ は同報告をきわめて貴重なデータとし てその内容を詳細に紹介しているが，線量関係 については，「放射線が胎児脳の発育を障害し て知能障害をもたらす過程の複雑性にかんが み，観察された線量一反応関係の 正当性を評価 することは困難で, “linearity” は慎重に取り扱 らべきである」(ICRP)，「本データを細胞生物 学の立場から説明できる学問的レベルに達して いない現状では, “linearity”は一つの観察所見 として受け止めるべきである」(UNSCEAR) とコメントしている。

\section{$3 \cdot 4 \cdot 3$ 学童の IQ 值, 学業成績}

放射線影響研究所の Schull and Otake (1986) ${ }^{42)}$ は，原爆子宮内被曝児の10-11歳の学 童期に行われた知能テスト(古賀式 $\mathrm{IQ}$ テスト) のデータについて被曝胎龄および被曝線量との 関連を分析した成績を発表している。重度精神 遅滞児を除く 1666 名の IQ 值データは表 5 に示す通 り, 胎生 8 週以前と胎生 26 週以後の被曝では影響は認 
められず，胎生 8-15週と 胎生16-25週の被㩧群の平 均 IQ 值は線量増加に伴。 て低下している。このデー タから線量 - 効果関係の形 は明らかでないが, 高感受 期が重度精神遅滞のデータ に一致する点から，著者ら は IQ 值の低下は偶然のも のではないと述べている。 学業成績は10-11歳時の 1091 名の 学童の国, 社, 数, 理, 音, 四, 体の 7 科 目の 5 段階評価点が用いら れ，7科目相互の間にはそ れぞれ高い相関が認めら れ, 胎生 8-15週と $16-25$ 週被曝群㳊射線量との間 に $5 \%$ 水準で有意の相関が 認められたと報告してい る43)。国, 社, 数, 理の評 価点が被曝胎秢との関連で $\mathrm{Q}$ 值データと 同じ傾向を 示すのはよいとして, 音, 図, 体の評価点も連動して いる点は興味深い。

ICRP Publ. 49 (1986) は IQ 值のデータを詳しく 引用しているが，IQ 值低下のリスクには言及してい ない。軽度精神遅滞と正常範囲の IQ 值の変異 variation には, 生物学的要因よりも社会文化的および心理 的要因の占める割合が大きい点にかんがみ, 線量-効 果関係についてはさらに検討が必要であうう。

\section{4. リスク評価について}

\section{$4 \cdot 1$ 大脳発達障害のリスク}

これまでのヒト脳発達障害の症例で, 線量および被 曝胎龄の情報が得られている点でリスク推定の資料と なり得るものは広島，長崎の原爆例のみであるが，こ れとても前章で述べたと和り不確定要素が少なくな い。しかも，低線量域での精神遅滞の発現を説明でき る生物学的知見が得られていない現状では，原爆例の みから量的リスクを推定することはきわめて難しい。 ICRP Publ. 49 (1986) と UNSCEAR 1986-Report は ともにこの点を強調しておきながら, Otake and Schull の重度精神遅滞のデータの線量 - 発現率関係より算出 した線量当たりのリスクを記載している。
ICRP Publ. 497)のリスク評価の項の記述の要点は, (1)原爆の胎生 8-15 週被曝群の重度精神遅滞の発現率 にしきい值のない直線性を仮定すれば，リスクは 0.4 $\mathrm{Gy}^{-1}$, (2)胎生 8-15 週被曝群について, 観察データに 適合する最大しきい值の算出は可能で，0-0.1 Gy の 間にしきい線量が存在する可能性は否定できない。(3) 胎生16-25週被曝群のリスクは 8-15週被曝群の $1 / 4$, 量関係は線形一 2 次関数モデルに適合し, $0.5 \mathrm{~Gy}$ よ り低いところにしきい線量が存在する可能性は否定で きない。(4) 8-15週执よび16-25週被曝の両群の小学 校学童期の平均 IQ 值は線量増加に伴って低下してい たが，線量関係の形は明らかでない。(5)胎生 8 週以前 と26週以後の被曝では, 重度精神遅滞および IQ 值低 下のリスクは 0 とみなしてょい。

\section{$4 \cdot 2$ 妊婦の職業被瀑と胎児のリスク}

ICRP Publ. 49 では上述の推定にもとづいてつぎの ようにコメントしている。(1ICRP の職業被曝につい ての勧告を守れば，重度精神連滞の最高感受期の 2 か 月間（胎生 8-15 週）に胎児は $1 \mathrm{mSv}$ 以上被曝する可 能性はなく，1 $\mathrm{mGy}$ 以上にしきい線量が存在すれば 胎児へのリスクはないことになる。(2)しきい值のない 
直線性を仮定した場合のリスクは，胎生 8-15 週 $4 \times$ $10^{-4}$, 胎生 $16-25$ 週 $1 \times 10^{-4}$, 全妊娠期間を通じて 5 $\times 10^{-4}$ を超えることはない。他方，広島，長崎の非被 曝群の重度精神遅膟の発現率は $8 \times 10^{-3}$ と高い。

上述のリスクについての ICRP のコメントが将来の 新しい勧告につながるものか否かは明らかでないが， 現時点では，不完全なデータではあるが胎児被曝の新 しい知見をらまえた ICRP からの問題提起と受け止め るべきであろら。胎児のための防護基準の設定に向け て，わが国においても積極的な検討がのぞまれる。

\section{5. おわりに}

大脳は発生の開始より成熟までの期間が他の器官に 比べ著しく長く，胎児脳には放射線感受性の高い未分 化神経系細胞が長い期間にわたって存在するため, 被 曝によって損傷を受ける危険期が長い。さらに大脳皮 質を構成するニューロンの産生は胎生中期に完了し, 以後再生しないため, 損傷が修復されることなく生涯 残る機能的欠陥をもたらす危険が大さい。これが放射 線被曝で大脳発達障害がとくに重視されるゆえんであ る。

ヒト胎児被曝による脳発達障害の実例は 42 年前の広 島，長崎の原爆例以外飞まとまったデータはなく，本 編で詳しく紹介した Otake and Schull $(1983,1984) の$ 再評価報告はきわめて貴重である。しかし，被曝線量， 被曝胎龄, その他精神遅滞の発現に関与する諸要因の 情報が限られている。精神漣滞の発現メカニズムの生 物学的基礎が確立していない現状で, 脳発達障害の量 的リスクの推定はきわめて困難といわざるを得ない。

将来にわたって新しいヒト疫学資料が期待できない 以上，この難問の解決への道はやはりメカニズムから のアプローチにまたねばならず，とくにヒト脳の正常 発生々動物々の比較発生学的研究々, 放射線誘発脳発 生異常の細胞レベルの解析が必要である。比較発生に はサルを含めての観察が必要であり，基礎的研究では 未熟神経細胞の遊走と神経回路網の形成を支配する カニズムの解析, 脳内の情報伝達機構の発達に及ぼす 放射線影響の形態学的，生理生化学的アプローチが望 まれる。

中枢神経系の発生, 分化はライフサイェンスのトピ ックスの一つとはい充，高次機能の発達の基礎的知見 がそしい現状では，早急に解決の道が拓けると期待す るのは無理であろう。遣伝, 発がんの基礎研究で輝か しい実績を持つ放射線生物学が，この分野でも先導的 役割を果たすことを期待したい。

\section{文献}

1) Blot, W.J. and Miller, R.W.: Radiology, 106, 617-619 (1973)

2）加藤寛夫 : 医学のあゆみ， 84，754-759（1973）

3) Miller, R.W. and Mulvihill, J.J.: Tetratology, 14, 335-358 (1976)

4) Plummer, G.: Pediatrics, 10, 687-693(1952)

5) Otake, M. and Schull, W.J.: Radiation Effects Research Foundation Technical Report 1-83 (1983)

6) Otake, M. and Schull, W.J.: Br. J. Radiol., 57, 409-414 (1984)

7) ICRP Publication 49: Developmental Effects of Irradiation on the Brain of the Embryo and Fetus, Annals of the ICRP, Vol. 16, No. 4, pp. 1-43, Pergamon Press, Oxford (1986)

8) United Nations: UNSCEAR Report-1986, IV. Biological Effects of Pre-natal Irradiation (1986)

9) Gardner, W.J.: Arch. Neurol., 4, 1-7 (1961)

10) Marin-Padilla, M.: Tetratology, 3, 34-46 (1970)

11) O'Rahilly, R. and Gardner, E.: "Handbook of Clinical Neurology, Vol. 30, (Eds. Vinken, P.J. and Bruyn, G.W.)", pp. 17-40, NorthHolland, New York (1977)

12) Dobbing, J. and Sands, J.: Arch. Dis. Child., 48, 757-767 (1973)

13) Dobbing, J.: "Scientific Foundation of Pediatrics, (Eds. Davis, J.A. and Dobbing, J.)", pp.565-577, William Heinemann Medical Books, London (1973)

14) Sidman, R.L. and Rakic, P.: "Histology and Histopathology of the Nervous System, (Eds. Haymaker, W. and Adams, R.D.)", pp.3-145, C.C. Thomas, Springfield, Virginia (1982)

15) Dobbing, J.: "Scientific Foundation of Pediatrics, 2nd Ed., (Eds. Davis, J.A. and Dobbing, J.)", pp. 741-759, William Heinemann Medical Books, London (1981)

16) Cowan, W.M., Fawcett, J.W., O'Leary, D.D. M. and Stanfield, B.B.: Science, 225, 12581265 (1984)

17) Rakic, P.: Trends in Neurosciences, 4, 184- 
187 (1981)

18) Edelman, G.M.: "Molecular Basis of Neural Development, (Eds. Edelman, G.M., Gall, W. R. and Cowan, W.M.)", pp.35-60, John Wiley, New York (1985)

19) Brizzee, K.R., Ordy, J.M., Kaack, M.B. and Beavers, T.: J. Neuropath. Exp. Neurol., 39, 523-540 (1980)

20) Kameyama, Y.: "Prevention of Physical and Mental Congenital Defects, Part A: The Scope of the Problem, (Ed. Marois, M.)", pp. 143156, Alan R. Liss. New York (1985)

21) Kameyama, Y., Hoshino, K. and Hayashi, Y.: "Developmental Toxicology of Energy-Related Pollutants, (Eds. Mahlum, D.D., Sikov, M.R., Hackett, P.L. and Andrew, F.D.)", pp. 228-236, U.S. Department of Energy, Oak Ridge (1978)

22）星野 清, 伊藤米子, 早坂 静, 亀山義郎 : 環 研年報，38，109-112（1987）

23) Warner, R.A. and Edwards, M.J.: $\mathrm{Br} . \mathrm{J}$. Radiol., 56, 33-39 (1983)

24) Hoshino, K. and Kameyama, Y.: Environ. Med., 27, 29-34 (1983)

25) Kameyama, Y. and Hoshino, K.: "Radiation Risks to the Developing Nervous System, (Eds. Kriegel, H., Schmahl, W., Gerber, G.B. and Stieve, F.E.)", pp.75-92, Gustav Fischer Verlag, Stuttgart (1986)

26）星野 清，伊藤米子，早坂 静，龟山義郎：環 研年報, 37, 131-133（1986）

27）亀山義郎，星野 清 : 「放射線の身体影響に関 する人体データと動物実験, 放医研シンポジウ ムシリーズ No.17，(松岡 理，小林定喜編)」, pp. 80-90，実業公報社，東京（1986）

28) Inouye, M. and Kameyama, Y.: J. Radiat. Res., 24, 259-269 (1983)

29) Konerman, G.: "Developmental Effects of Prenatal Irradiation, (Eds. Kriegel, H., Schmahl, W., Kistner, G. and Stieve, F.E.)", pp. 237-250, Gustav Fischer Verlag, Stuttgart
(1982)

30) Konerman, G.: "Radiation Risks to the Developing Nervous System, (Eds. Kriegel, H., Schmahl, W., Gerber, G.B. and Stieve, F.E.)", pp. 93-116, Gustav Fischer Verlag, Stuttgart (1986)

31) Murphy, D.P.: Am. J. Obstet. Gynecol.,18, 179-187 (1929)

32) Dekaban, A.S.: J. Nucl. Med., 9, 471-477 (1968)

33) Granroth, G.: Am. J. Obstet. Gynecol., 133, 191-194 (1979)

34) Neumeister, K.: "Late Biological Effects of Ionizing Radiation upon the Human Fetus", Vol. 1, pp.119-134, IAEA, Vienna (1978)

35) Oppenheim, B.E., Griem, M.L. and Meier, P.: "Biological and Environmental Effects of LowLevel Radiation, II”, pp.249-260, IAEA, Vienna (1976)

36) Omran, A.R., Shore, R.E., Markoff, R.A. et al.: Am. J. Public Health, 68, 561-567 (1978)

37) Ron, E., Modan, B., Floro, S. et al.: Am. J. Epidemiol., 116, 149-160 (1982)

38) Neriishi, S. and Matsumura, H.: J. Radiat. Res., 24, 18 (1983)

39）横田素一郎, 田川大吉郎, 大津留 信, 他 : 長 崎医学会雑誌, 38，92-95（1963）

40) Ishimaru, T., Nakashima, E. and Kawamoto, S.: Radiation Effects Research Foundation Technical Report 19-84 (1984)

41) Milton, R.C. and Shohoji, T.: Atomic Bomb Casualty Commission Technical Report 1-68 (1968)

42) Schull, W.J. and Otake, M.: Radiation Effects Research Foundation Technical Report 7-86 (1986)

43）大竹正徳，Schull, W.J.: 「放射線の身体影響に 関する人体データと動物実験, 放医研シンポジ ウムシリーズ No. 17, (松岡 理, 小林定喜編)」 pp. 69-79，実業公報社，東京（1986） 